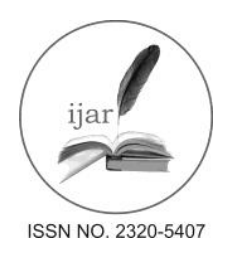

Journal homepage:http://www.journalijar.com
Journal DOI:10.21474/IJAR01

RESEARCH ARTICLE

\title{
INHIBITING FACTORS RESPONSIBLE FOR LAND AND PROPERTY OWNERSHIP OF FARM WOMEN.
}

\author{
Sarita Devi, Dr. Neelma Kunwar, Dr.Sheela Kumari \\ Research Scholar, Extension Education and Communication Management, Maharani Avantibai College of Home \\ Science, Chandra Shekhar Azad University Of Agriculture and Technology, Kanpur Uttar Pradesh, India.
}

\section{Manuscript Info}

Manuscript History:

Received: 18 March 2016

Final Accepted: 16 April 2016

Published Online: May 2016

Key words:

Inhibiting, factors, responsible, ownership, farm women, land and property

*Corresponding Author

Sarita Devi.

\begin{abstract}
The present paper describe about the inhibiting factors responsible for land and property ownership of farm women. The study was conducted in 20 villages of Bikapur Block of Faizabad district of Uttar Pradesh. The sample comprised of purposively selected 300 farm women i.e. 15 farm women from each of the 20 selected villages. All the respondents perceived and expressed the inhibiting factors in land and property ownership. From the findings of the study it could be thus inferred that lack of awareness of land and property rights, lack of involvement in agricultural decision making, women not allowed to interfere in land and property discussion. Expert group consisting of women activities legal experts, academicians should be formulated to draft "Basic principles for women's rights to property" so as to promote, protect and enforce women's rights to property at the local regional and national level.
\end{abstract}

Copy Right, IJAR, 2016,. All rights reserved.

\section{Introduction:-}

Across the developing world, rural women are among the most disadvantaged people. Widespread gender based discrimination in laws, customs and practices cause severe inequalities in their ability to access and control land and other natural resources, and limit their participation in decision-making in land governance, from the household to local and national institutions.

Women have a very important involvement in agriculture and most of the hard work is done by them, involved as they are in heavy physical labour in the field as well as the totality of domestic chores. But notwithstanding this, most of the land is in the name of the male family members. Also, as is the custom, the our tradition in the region transfers their property and land rights to their sons. Even a widow would have a right to her land only if she has a male child through her husband. A childless widow has no property rights. Added to this is the low level of literacy among women that has made them easy, vulnerable victims of deceit and forgery. Moreover, the local system of witch hunting has made it a traditional practice to ostracise helpless women in order to grab their land or house, indigenous people, migrants, displaced people or refugees. They are also disadvantaged and marginalized by a lack of knowledge and recognition of their land and property rights as well as by the obstacles they meet in getting access to information about land and property. While women are increasingly using the legal system to exercise their rights, in many countries lack of awareness of the existence of these rights is an obstacle to full enjoyment of their land and property rights and the attainment of equality. Experience in many countries has shown that women can be empowered and motivated to assert their rights, regardless of their level of education or socio-economic status. Legal literacy programmes and media strategies have been effective in helping women to understand the link between their rights and other aspects of their lives and in demonstrating that cost-effective initiatives can be undertaken to help women obtain those rights. Provision of human rights education is essential for promoting an understanding of the land and property rights of women, including knowledge of their rights. 
There are some inhibiting factors:

1. Dual burden of household and agricultural work.

2. Lack of awareness of land and property rights.

3. Lack of education.

4. Family insecurity.

5. High status and income of husband.

6. Lack of emotional attachment with family members.

7. Lack of decision-making in family affairs.

8. Lack of involvement in agricultural decision making.

9. Problem related to physical health pregnancy etc.

10. Women not allowed to interfere in land property discussion.

\section{Research methodology:-}

The present study was conducted in purposively selected 20 villages of bikapur block of faizabad district of U.P. Keeping in mind the objective of the present study,300 farm women were selected. For selecting the 300 farm women a list of such women who were engaged in farm activities was prepared with the help of farmers(block officers) and informal (village leaders, school teachers, aganwadi workers) sources. From the list 300 farm women were selected randomly from each of 20 villages.

\section{Selection and construction of tool:-}

For accomplishing the present investigation, interview technique was used to get the information from farm women. For this purpose interview schedule was prepared by the review of literature. This included questions pertaining to inhibiting factors responsible for land and property ownership of farm women.

\section{Observation and analysis:-}

In the present study the inhibiting factors responsible for land and property ownership that they perceived in land and property rights.

Inhibiting factors responsible for land and property ownership of farm women:-

Table 1. Distribution of farm women according to their inhibiting factors of land and property ownership(N=300)

\begin{tabular}{|c|c|c|c|c|c|c|}
\hline Sl.No. & Inhibiting factors & Yes & No & Mean Scores & Rank & Graph code \\
\hline 2. & $\begin{array}{l}\text { Lack of awareness of land and property } \\
\text { rights }\end{array}$ & $278(92.7)$ & $22(7.3)$ & 1.93 & $\mathrm{I}$ & $\mathrm{b}$ \\
\hline 3. & Lack of education & $216(72.0)$ & $84(28.0)$ & 1.72 & VI & $\mathrm{c}$ \\
\hline 4. & Insecurity about negligence & $248(82.7)$ & $52(17.3)$ & 1.83 & IV & $\mathrm{d}$ \\
\hline 5. & High status and income of husband & $76(25.3)$ & $224(74.7)$ & 1.25 & $\mathrm{X}$ & $\mathrm{e}$ \\
\hline 7. & Lack of decision making in family affairs & $172(57.3)$ & $128(42.7)$ & 1.57 & VIII & g \\
\hline 8. & $\begin{array}{l}\text { Lack of involvement in agricultural } \\
\text { decision making }\end{array}$ & $275(91.7)$ & $25(8.3)$ & 1.92 & II & $\mathrm{h}$ \\
\hline 9. & $\begin{array}{l}\text { Problems related to physical } \\
\text { health/pregnancy }\end{array}$ & $185(61.7)$ & $115(38.3)$ & 1.62 & VII & I \\
\hline
\end{tabular}

(Figures in parenthesis indicate percentage of respective values)

The perusal of Table 5.34 reveals that inhibiting factors involved in land and property ownership, 92.7 per cent of farm women have lack of awareness of land and property rights with mean score 1.93 ranked I, whereas 91.7 per cent of farm women were having lack of involvement in agricultural decision making with mean score 1.92 ranked II. 86.7 per cent of farm women were having inhibiting factors women not allowed in land and property decision with mean score 1.87 ranked III, whereas, 82.7 per cent of farm women have insecurity about negligence with mean score 1.83 ranked IV. 82.0 per cent of farm women have dual burden of household and agricultural work with mean 
score 1.82 ranked $\mathrm{V}$ while 72.0 per cent of farm women were having lack of education with mean score 1.72 ranked VI. 61.7 per cent of farm women having problems related to physical health with mean score 1.62 ranked VII and 57.3 per cent of farm women have lack of decision making in family affairs with mean score 1.57 ranked VIII

The socio-cultural attributes in society have left a deep mark on women empowerment in India. Parents depend on sons for support in old age and looked to them as potential builders of family prestige and prosperity whereas daughters are considered to destine for others. Women's in India need and expect equal access to education, health, nutrition, employment and productive resources in fact they are fighting for their rights to decide their own path for development.

\section{Dual burden of work:-}

In the study it was found that majority of the farm women said that they have faced various problems related in household and agricultural affairs which was inhibited them to take their right in land and property like as dual burden of household and agricultural work they have no time for other activities for reading or taking information which was related with their rights on land and property.

\section{Lack of awareness and education:-}

In rural community majority of women said that they have faced problem which was related to awareness they have no knowledge about land and property rights due to lack of awareness it was a major obstacles that they faced they said that they cannot fight for their right due to absence of awareness. And the main reason of lack of a wareness is lack of education they said that they were illiterate and they cannot read and write so how they were aware about their right they also said that they have no other resources to give awareness on land and property rights. In rural area women are not much educated so they were no knowledge about land and property rights and our custom does not allow them to interfere on land and property discussion, because they were lived in a male dominating society where women was not involved in discussion on agricultural issues.

\section{Lack of decision making in family affairs:-}

The granting of marital power to one spouse (generally the husband) over the other (generally the wife), as well as over joint property, is a provision in some civil and customary legal systems which runs deeply counter to the right to equality between men and women. Marital power assumes that husbands are the heads of the household or legal representatives of households, with the authority to make decision on behalf of the couple or family without the consent of their spouse/s, including exclusive rights to administer property. International human rights law is clear on the prohibition of marital power.

\section{High status and income of husband:-}

Women will have little to say over how land is used to generate income or to support families. However, when the husbands have highest level of education and property ownership, their wives land ownership is sinking down, almost similar to husbands who have never been to school. There might be several factors that discourage wives to own land ownership problems, the survey has revealed that a husband's potential support is important for bringing changes in women's live. In many parts of the world, women's rights to land and property are denied. The existing laws give women fewer or less secure rights than men and inequitable and discriminatory attitudes and practices undermine them.

\section{Physical health and pregnancy:-}

The most important inhibiting factor was that ill physical health of women due to low intake of sufficient nutritional diet. Women cannot take food before eating of male member of the family. Pregnancy was also a major reason for inhibiting women to take their right because in this condition women cannot do anything on field. Few farm women said that if they do not work on field so how their decision was taken on agricultural affairs.

\section{Insecurity of husband:-}

Some farm women said that their husband think if they purchased any property on their wife name then they have a feeling of insecurity like as their wife leave them, sell the property and give the money for their paternal home. So feeling of insecurity of their husband was inhibited them to buy land and property on their name. For improving women status in society there was need to give equal right in land and property of women and for this first of all removing all the inhibiting factors which inhibit women to take their right in land and property. 


\section{Summary and conclusion:-}

1. The socio-cultural attributes in society have left a deep mark on women empowerment in India. Parents depend on sons for support in old age and looked to them as potential builders of family prestige and prosperity whereas daughters are considered to destine for others. Women's in India need and expect equal access to education, health, nutrition, employment and productive resources in fact they are fighting for their rights to decide their own path for development. For improving women status in society there was need to give equal right in land and property of women and for this first of all removing all the inhibiting factors which inhibit women to take their right in land and property.

\section{Review:-}

Kodoth (2013) stated that the structures and practices of families are crucial in determining gender-differentiated patterns of access to land and other forms of property/productive resources. However, major redistribution or reform programmes such as that of land have failed to take this into account. This paper addresses, conceptually, women's and men's claims to land/property in terms of via more recent land reforms experience to discuss the importance to property reform of a gendered understanding of the family. Besides, it attempts to probe the direction of change in property-related practices, including inheritance, dowry and residence, in contemporary Kerala to understand the implications of the emerging practices for women's property rights.

Amaral (2014) studied that the effect of women's improved access to inheritance on violence committed against them. It was found that staggered implementation of the Hindu Succession Act across states to identify the causal impact of the legislative amendments on police reported violence against women and on self reported intimate partner violence. There was a decrease in reported violence following the amendments and this effect is not due to changes in reporting behaviour or a generalized decrease in crime. Further, women eligible to inheritance are 17 per cent less likely to be victims of domestic violence. These findings are explained by an improvement in husbands' behaviour and in marriage market negotiations. It was found that the weak evidence of changes in women's decision making. This suggests that while inheritance legislation improves women's security, this may be necessarily being due to changes in empowerment.

\section{References:-}

1. Amaral, S. (2014). Do improved property rights decrease violence against women in India. http://papers.SSRn.com/5013/papers.cfm?abstract id=2504579.

2. Kodoth, P. (2013). Gender, family and property rights question from Kerala's land reforms. http://ij.sagepub.com/content/8/2/291.shart June 2013. 